\title{
Az MDA modell alapján történő gamification módszertan felsőoktatási környezethez igazított adaptációjának vizsgálata ${ }^{1}$
}

\author{
Mezeiová Adriana - Bencsik Andrea
}

\begin{abstract}
The examination of the MDA model-based gamification methodology adapted to the higher educational environment

Abstract

Today the most pressing global problem in education that all teachers and educators face is the difficulty to awaken students' natural curiosity and motivation. The study shows how technology changes our brains and explains why young people's stimulus threshold is higher. The focus of this study is on gamification methodology. Gamification uses game elements in a non-gaming environment. Game designers have used it successfully for decades and they are still using it to improve their gamification method. The purpose of this study is to explain in detail the logical structure and relationships of the method through the MDA (Mechanics, Dynamics, Aesthetics) model, which incorporates elements of game mechanics, game dynamics and aesthetics (enjoyment). It highlights the importance of optimal pressure, correctly chosen leveling and reward system. The study points out that the logic followed by game developers can contribute to the success of the gamification method used in education.
\end{abstract}

Keywords: gamification; motivation; the effect of media; neuroplasticity; the MDA model

Kulcsszavak: játékosítás; motiváció; a média hatása; neuroplaszticitás; az MDA modell

Subject-Affiliation in New CEEOL: Social Sciences - Education - School Education

DOI: $10.36007 /$ eruedu.2020.2.034-046

1 A tudományos cikk a komáromi Selye János Egyetem Gazdaságtudományi Karán futó KEGA 005UJS4/2019 -es „Y és Z generáció menedzseri szakértelem hatékonyságának növelése a gamifikáció révén a tudomány és gyakorlat kontextusában" elnevezésű projekt részeredménye.

The scientific article is a partial result of the project KEGA 005UJS-4/2019 „The improvement of the efficacy of management proficiency of the $Y$ and $Z$ generations through gamification in the context of science and practice". 


\section{Bevezetés}

A Z generációhoz tartozó fiatalok alkotják napjaink egyetemistáinak többségét. Az első hullám gyermekei (1995 és 2000 közötti születésűek) ott voltak a digitális korszak kezdetén. A második hullámban született gyermekek (2005-2010 közöttiek) már beleszülettek a digitális világba. Ebben a világban már jelen kell lenni a közösségi oldalakon, és magától értetődő az on-demand szórakozás (akkor, amikor akarom). Számukra az élet természetes része a társadalom minden szegmensét betöltő infokommunikációs technológia (IKT). Élvezik és maximálisan ki akarják használni a lehetőségeket, a mának élnek, kevesebbet beszélnek és rövidebben fogalmaznak (Tari 2015).

Számos pedagógus tette már fel magának a következö kérdéseket: Hogyan motiváljam őket? Miért nem kapcsolódnak be az órai munkába? Tényleg semmi sem érdekli őket? Miért ilyen figyelmetlenek és szétszórtak? A szülők meg ezt kérdezik maguktól: Hogyan képesek hosszú órákon keresztül, maximálisan koncentrálva, a kedvenc videojátékukkal játszani? A kérdéseknél némi ellentmondást tapasztalhatunk. A pedagógusok úgy látják, hogy az egyetemisták többsége figyelmetlen, szétszórt, motiválatlan, a szülök pedig arról panaszkodnak, hogy órákig a videójátékok felett ülnek. Felvetődik a kérdés: Miért olyan sikeresek és népszerüek, korcsoportoktól függetlenül, a videójátékok? Hogyan csinálják? Hogyan motiválják a játékosokat és vonzzák be őket a virtuális világukba? A tanulmány ezekre a kérdésekre keresi a választ. A videójátékok készítői mesterei a gamification módszernek. Ez a módszer magába foglalja a pszichológiát, a játéktervezést, a pozitiv felhasználói élményre való rendületlen törekvést és a viselkedés-gazdaságtan elemeit is.

A tanulmány rámutat a technológia agyra kifejtett hatására, meghatározza a gamification fogalmát. Részletesen bemutatja a módszer egyik alapmodelljét, az MDA (Mechanics, Dinamics, Aesthetics) modellt. Ismerteti a játékmechanika és játékdinamika egyes elemeit, felvázolja a közöttük lévő kapcsolatot. Ha motiválni akarjuk a fiatal nemzedéket, meg kell ismernünk az MDA logikáját, az egyes elemeit és a közöttük lévő kapcsolatokat. Ebben nyújt segítséget ez a tanulmány. Ha tisztában vagyunk a modell müködésével, akkor sikeresen adaptálhatjuk az oktatásba az MDA modellt, így kidolgozhatunk egy gamification alapú oktatási módszert, mely kellőképpen motiválja a hallgatót és az oktatót is.

\section{Mi a „baj” a mai fiatalokkal?}

Napjainkban egyre gyakoribb téma, hogy milyen nehéz fenntartani a tanulók, hallgatók figyelmét, motivációját. Pár percnél tovább képtelenek egy dologra figyelni, és folyton a kijelzökön „lógnak”. Másrészt viszont azt tapasztaljuk, hogy képesek (?) párhuzamosan zenét hallgatni, a böngészőben keresgélni, beszélgetni barátaikkal, miközben tévét néznek. Néhány tudós úgy véli, hogy ez a figyelmetlenség (szétszórtság) a digitális világunk velejárója, hiszen az emberi agy már képtelen olyan gyorsan fejlődni, mint amilyen gyorsan az általa létrehozott technológia. Számos tanulmány foglalkozott a média emberi agyra és viselkedésre kifejtett hatásá- 
val. Egyes kutatások kimutatták (Vakenburg - Jochen 2016; Uncapher - Wagner 2018; Crone - Konijn 2018), hogy a média megváltoztatja szokásainkat és rutinjainkat. Carr (2010) úgy írta le saját érzéseit, hogy az agya folyton éhes, és követelte, hogy az internet a maga módján táplálja - de minél többet kapott, annál éhesebb lett. Ma már tudjuk, hogy az agyunk folyamatosan változik, s a körülmények és a magatartás legapróbb változásához is alkalmazkodik. Ezt a csodálatos tulajdonságot plaszticitásnak, képlékenységnek nevezik. A rugalmasság ebben az esetben helytelen kifejezés, mert a változás után az agy nem áll vissza az eredeti, kiinduló állapotába, hanem a megváltozott állapotban marad. Nem törvényszerü, hogy az új állapot mindig kívánatos legyen. Rossz szokásaink ugyanolyan könnyen rögzülhetnek, mint a jók. A neuroplaszticitás az evolúció legfontosabb eredménye, mely lehetővé teszi, hogy az egyén egész élete során, vagy akár néhány nap leforgása alatt igazodjon a megváltozott körülményekhez és újra átszervezze saját magát (Hanson 2017; Price - Duman 2019).

Serdülökorban az agyban jelentős változások mennek végbe. Azok az idegsejtek, amelyeket nem használnak rendszeresen, elhalnak, így megtörténhet, hogy a középiskolában jó teljesítményt nyújtó diákok a föiskolán vagy az egyetemen azért vallanak kudarcot, mert agyuk gyenge funkcióit túlterheli a megnövekedett igénybevétel (Carr 2010). Másrészt az ingergazdag környezet és a megfelelö, állandó stimuláció kimutathatóan fejleszti az agyat.

A játék az életünk és fejlődésünk fontos része. A játék segítségével tanulja meg a gyermek a legfontosabb társadalmi szabályokat és a viselkedési normákat. Számos kutatás alátámasztja, hogy a játékos tanulás hatékonyan erősiti az agy gyengébb területeit, gyermekeknél és felnőtteknél egyaránt. A tanulás által növekszik az idegsejtek közötti kapcsolatok száma. Mivel ezekhez több nyúlvány szükséges, az idegsejtek messzebb kerülnek egymástól, nagyobb lesz az agy térfogata és sürüsége. Az az elgondolás, hogy az agyunk a gyakorlástól hasonlóképpen fejlödik, mint az izom, nem alaptalan.

A technológiának van a legnagyobb hatása az emberi agyra. Minden technológia az emberi akarat megnyilvánulásából jött létre. Eszközeinket arra használjuk, hogy befolyásoljuk környezetünket vagy másokat. A technológiát aszerint, hogy miképp egészítik vagy erösítik meg a velünk született képességeinket, alapjában véve négy nagy csoportba oszthatjuk.

Az első csoportba azokat a technológiákat soroljuk, amelyek a fizikai erönket, kézügyességünket és rugalmasságunkat fokozzák (pl. eke, repülögép). A második csoportba tartozók az érzékszerveink tartományát vagy érzékenységünket növelik (pl. mikroszkóp). A harmadik magát a természetet igazítja az emberi szükségletekhez (pl. génmódosítás). A negyedik csoportba tartotó eszközök a szellemi képességünket támogatják vagy bővítik ki, segítik megtalálni a szükséges ismereteket, megfogalmazni és megosztani know-how tudásunkat, ezért intellektuális technológiának is nevezik. Ide soroljuk az írógépet, a földgömböt, a könyveket, a számítógépet és az internetet is. Az intellektuális technológiához tartozó eszközöknek van a legnagyobb befolyásuk arra, hogy mit és hogy hogyan gondolunk. $A z$ internet egy fontos szempontból különbözik a médiaeszközök többségétöl: a világháló kétirányú. A hálózaton keresztül küldhetünk és fogadhatunk üzeneteket. Egy 
webes dokumentum olvasásához teljesen más érzékszervi ingerekre van szükség, mint egy nyomtatott könyv vagy újság olvasásához, amely nemcsak a látásra, de a tapintásra is támaszkodik és azt is befolyásolja, mennyire „merülünk” el benne. A multimediális internet, a sok különböző információ egy képernyőre történő sűrítése még jobban megzavarja és csökkenti a koncentrációnk idejét. Számos kutatás rámutat arra a tényre, hogy ha csak két feladat között kell váltanunk, az is megzavarja gondolkodásunkat, és nagyban megnöveli kognitív terhelésünket, miként annak a valószinüségét is, hogy egy fontos információt nem regisztrálunk (Kirschner - Karpinski 2010; Junco - Cotten 2012).

A tudósok kísérletükben két csoportot vizsgáltak. Az egyik csoport elektronikus hiperszöveges (a szöveg egy bizonyos pontjáról egy másik szövegre hivatkozunk) dokumentumokkal dolgozott, míg a másik hagyományos, nyomtatott, papíralapú iratokkal. Azt feltételezték, hogy a hiperszöveges dokumentumokkal dolgozó csoport tagjainál csökkennek a megismerési problémák, azaz jobb eredményt érnek el. Nem így történt. A lineáris szöveget olvasók többet értettek és tanultak meg, mint a hivatkozásokkal teletüzdelt elektronikus dokumentumot olvasók (Mial - Dobson 2001). További kutatások rámutattak még egy érdekes tényre. Minél tovább használjuk a világhálót, annál nehezebben tudunk egy hosszabb szövegre összpontosítani. Nielsen (2006) az internetfelhasználók körében szemkamera-kutatást végzett, mely során nyomon követte a szem mozgását. Arra a megállapításra jutott, hogy az online olvasás nagyban eltér a nyomtatott szöveg olvasásától. Míg a könyveket, újságokat lineárisan olvassuk, addig a világhálón a szemünk az $\mathrm{F}$ betü alakjához hasonlóképpen szalad végig az oldalon. Az online olvasásnak ezt a mintázatát a Software Usability Research Laboratory további kutatásai is alátámasztották (Nicholas - Rowland - Jamaji 2010; Shresta - Lenz 2007). Karp (2008) is azon a véleményen van, hogy a lineáris elménket, amelynek nem lehet elterelni a figyelmét, felváltja egy újfajta elme, mely rövid és feldarabolt információkat kénytelen minél gyorsabban magába szívni.

Napjaink egyetemistái a Z generáció tagjai (1995 és 2010 között születtek). Gyermekkoruktól a multimédiás eszközökön nőttek fel. A tanulmányok alátámasztják, hogy azon gyermekek agya, akik hosszabb ideig nézik a tévé képernyőjén vagy a monitoron a gyorsan mozgó képeket, hozzászokik a való életnél magasabb ingerszinthez, és ezt a valóságban is elvárja (Christakis 2011). A hagyományos oktatás, amikor is a tanár kiáll a diákok elé és elmondja a tananyagot, a már gyerekkoruktól magasabb ingerszinthez szokott fiatalok figyelmét nem köti le (Mezeiová - Bencsik 2019).

Visszatérve a fejezet címéhez, a mai fiatalokkal nincsen semmi baj, teljesen rendben vannak. A multimédiás eszközök napi több órás használatának következményeként agyuk alkalmazkodott, átrendeződött az agyi térképük. Úgy is mondhatjuk: másképp „működik” az agyuk, mint a szüleiknek. Állandó interakciót és megnyilvánulási lehetőségeket várnak el a tanórákon is (Steigerwald 2014). Az egyik lehetséges módja annak, hogy felkeltsük a hallgatók figyelmét és motivációját, a gamification (játékosítás). Számos kutatás alátámasztja, hogy a játékok segítségével sokkal mélyebben és nagyobb alapossággal ivódik be a tudás, gyermekeknél és felnőtteknél egyaránt (Kapp 2012). 


\section{Miért szeretünk játszani?}

A gyermek legelőször az anyával való kapcsolatán belül ismeri meg a játékot. Később az óvodában, iskolában a különböző csoportjátékok segítségével kommunikációs formát, szociális mintát és tevékenységet sajátítanak el. A játék a gyermek természetes nyelve és egyben a tanulásának és kommunikációjának a legfontosabb eszköze is. Ha szeretnénk megérteni öt, közel kerülni hozzá, megtanitani neki valamit, segíteni nehézségei leküzdésében, akkor mindehhez elsősorban a játékon keresztül vezet út (Mezeiová 2018).

Régebben a játék legfőképp a gyerekek egyik szórakozási formája volt, ma a technológiafejlődés elhozta a játékok reneszánszát. A játék során új szerepeket és helyzeteket élhetünk meg, felfedezhetjük saját határainkat és kreativitásunkat. Gyakran annyira elmerülünk benne, hogy megfeledkezünk a külvilágról és egy különleges állapotba kerülünk. Csikszentmihályi (1997) ezt az állapotot flow-élménynek nevezte. Ebben az állapotban a személy maximálisan motivált és az adott feladatra összpontosít. Az ember képes teljesen egy dologra figyelni, és megfelelöen átélni saját érzelmeit a legjobb teljesitmény vagy tanulás végett. A flow kutatói szerin ezen keresztül az emberek olyan belső, intrinzik jutalmakat nyerhetnek, melyek a kitartásra ösztönöznek. A gamifikáció is a játékelemek segítségével a belsö motivációra helyezi a hangsúlyt, és arra törekszik, hogy a folyamatban részt vevők flow állapotba kerüljenek.

\section{A gamification fogalma - avagy motiváció vagy manipuláció?}

Nincs egyértelmü, elfogadott definíció arra, hogy mi is a gamification. Maga a fogalom ugyan csak 2010 után robbant be a köztudatba, de a játékositás elvét már Napoleon Bonaparte idejében alkalmazták. Abban az időben a skorbutos megbetegedés - amely az éhezés és a C-vitamin hiányából fakadt - nagyobb pusztitást végzett a hadseregben, mint az ellenség. A francia belügyminisztérium versenyt hirdetett, 12000 frankot ígért annak, aki megoldja a hadsereg ellátását. Számtalan ember próbálta megszerezni a jutalmat. A XVIII. század végén Appert ennek kapcsán fedezte fel, hogy a hőkezelt élelmiszerek tovább megtartják frissességüket, így megnyerte a versenyt, megszületett az első konzerv. A játéknak köszönhetően már Pasteur elött feltalálta a „pasztörizálási” eljárást.

A játékositás számos területet érint: alkalmazott pszichológiát, játéktervezést, felhasználói élményt, viselkedés-gazdaságtant. A legszélesebb körben elfogadott definíciója szerint a gamification a játékelemek és mechanikák játékon kívüli környezetben történő alkalmazása (Deterding 2011). Raftopolous (2015), a vállalati játékositás egyik jeles kutatója szerint a játékositás összes definíciója helyes. Kapp (2012) szerint a játékositás olyan stratégia, melynek célja a felhasználók viselkedésének pozitív irányba történő változtatása a játéktervezés és a játékesztétika elemeinek alkalmazásával. Huotari és Hamari (2017) a játékosítást mint szolgáltatást fejlesztő folyamatot közelítik meg, ahol is a játékszerủ élmény létrehozásával támogatjuk a felhasználói értékalkotást. 
Néhány szakember úgy véli, hogy mivel a játékosítás célja az, hogy egy bizonyos viselkedésre késztessük az embereket, ezzel tulajdonképpen manipuláljuk őket. Ez bizonyos etikai kérdéseket vet fel. Yu-kai Chou, a játékosítás elismert szakembere szerint erre a kérdésre nincs jó válasz. Ö maga úgy véli, hogy a „manipuláció” fogalma hatalmas negatívumot hordoz, holott a mindennapi életben rendszeresen elfogadjuk, sőt el is várjuk. Például ha a barátunk „,megkér” minket egy szívességre, és mi megtesszük vagy forditva. Azon a véleményen van, hogy a játékositás is egyfajta manipuláció. Sok függ attól, mit tekintünk „manipulációnak”. Személy szerint a játékositást nem tartom manipulációnak. A manipuláció során a befogadó nincs tudatában a befolyásoló szándékának, leginkább a „megtévesztés” kifejezés jellemzi. A gamification folyamatában a befogadó részéről már elejétől fogva ismert a másik fél szándéka és célja, így önszántából dönthet arról, hogy részt vesz-e a játékban. Hogy jobban megértsük, miért olyan népszerüek napjainkban a videójátékok, és alkalmazni tudjuk azok elemeit az oktatásban, meg kell ismernünk, milyen logikai struktúra szerint épül fel a gamifikáció.

\section{A gamifikáció hatásmechanizmusai}

A gamifikáció logikája a játéktervezés eszköztárának és a pszichológiának az ötvözete. Három fő szintre oszthatjuk fel, melyek magukba foglalják a szabályozási, viselkedésbeli és érzelmi összetevőit, amit MDA modellnek is neveznek (1. ábra).

\section{Szabályok}
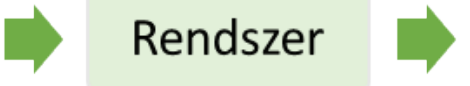

\section{Élvezet}

1. ábra: A játék keretrendszere - az MDA modell

Forrás: Hunicke - Leblanc - Zubek (2004)

Tényezőkre lebontva megfogalmazhatjuk a játékosított rendszer mechanikáját, dinamikáját és esztétikáját (2. ábra).

Mechanizmus

(Mechanics)

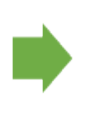

Dinamizmus

(Dynamics)

\section{Esztétika}

(Aesthetic)

2. ábra: Az AMD modell a tervezés szempontjából

Forrás: Hunicke - Leblanc - Zubek (2004)

Játékmechanikák alatt azokat a tényezőket értjük, melyek a játék folyamatában befolyásolják a személy cselekvését és viselkedését (Fromann 2017). Úgy is tekinthetünk rá, mint a játék szerszámosládájára, ahol egy művet különböző játékelemekből épithetünk fel. A legfontosabb játéképítő elemek a kihívások, a csapatok, 
az esélyek, a hírnév, az időbeli korlát, a pontok, a szintek, a ranglisták, az ajándékozás. A játékosítás során ezeknek az elemeknek a kombinációja elörevetíti a felhasználónak azt, hogy hogyan tudja elérni a kitüzött célt.

A Bunchball (2010) rendszer a játékmechanika változóit funkciójuk szerint hat fö kategóriába sorolja:

Pontok (points). Alapvető funkciója a folyamatos visszajelzés, a fejlődés nyomon követése. A gamification ötféle pontot különböztet meg:

- tapasztalati pontok (aktivitásért járó),

- beváltható pontok (virtuális fizetőeszköz),

- szakértelempontok,

- karmapontok,

- elismerési pontok.

Szintek (levels). Az ösztönzörendszer fontos komponensei. Hogy fenntartsuk a motivációt, a kezdeti alapszintet úgy kell beállítani, hogy könnyen teljesithető legyen. Fontos továbbá, hogy a szintek logikusan épüljenek egymásra, bővithetők és rugalmasak legyenek.

Kihívások és küldetések (challenges and quests). A felhasználó elé táruló problémát, helyzetet jelenti. Ezen akadályok megoldásával a résztvevők kapják meg azokat a pontokat, melyek segítségével szintet tudnak lépni.

Virtuális javak (virtual goods). A sikeres feladat elvégzéséért nemcsak pontokat, hanem virtuális, játékon belüli javakat kaphatnak, melyek komoly státuszszimbólumnak is minősülhetnek.

Ranglisták (leaderboards). Egyéni igényeket elégitenek ki és lehetőséget adnak a résztvevők eredményeinek egymáshoz való viszonyítására. Voltaképp egy eredményjelző tábla, amely a játékosokat csökkenő sorrendben rendezi el az általuk elért pontszám vagy a szintjük alapján. Ha a résztvevő látja, milyen helyet foglal el, pozitivan befolyásolja motivációját. A napi és heti ranglisták nagyobb ösztönző erövel rendelkeznek, hiszen ha naponta vagy hetente nullázódnak a pontok, akkor nagyobb az esély a fejlődésre és a ranglistán belüli haladásra azoknak is, akik később csatlakoztak.

Ajándékok (gifts and charity). Az ajándékok a virtuális javakhoz hasonlóak. A kettő között az a különbség, hogy az ajándék átruházható más felhasználóra, míg a virtuális javaknál nincs ilyen lehetőség (Fromann 2017).

A játékdinamika leírja a játékmechanizmusok müködését a játékosok viselkedésétöl függően. Akkor jelenik meg, amikor a részvevő kapcsolatba kerül azokkal a játékmechanikai elemekkel, melyek hatással vannak különböző igényeire és vágyaira. A Bunchball (2010) rendszere a következő játékdinamikákat különbözteti meg: Jutalmazás (reward). Minden esetben pozitív visszajelzés a játékos számára és egyben örömmel tölti el. A jutalmazás történhet a játékmechanika komponensei által: pontok, szintlepés vagy virtuális javak formájában. 
Státusz (status). Az egyik legerösebb ösztönző tényező. Az emberek többsége vágyik az elismerésre, tiszteletre és a hírnévre. A gamifikációs folyamatokban fontos, hogy a felhasználónak legyen lehetősége a státusz megszerzésére.

Teljesítés (achievement). Sok ember képes hosszan tartó, komoly eröfeszítésekre annak érdekében, hogy elérjen egy bizonyos célt és nyerjen. Fontos, hogy a célok valódi kihivást jelentsenek a résztvevőknek. Itt is érvényes az „arany középút” elve. Ha túl könnyű teljesíteni a feladatot, elveszik a kihívás, viszont ha túl nehéz, akkor az demotiváló is lehet.

Önkifejezés (self-expressions). Az önkifejezés a valós életben és a játékok világában is fontos szerepet játszik. A felhasználónak lehetőséget kínál az autonómiára, az egyedisége kibontakozására. Jó példa erre egy avatár létrehozása - mikor a résztvevő egy ikont, képet vagy fényképet választ, amely képviseli öt - és alakítása.

Versengés (competition). A verseny erős motivációt jelent a játékos számára. Általában magasabb szintű teljesitmény érhető el, ha egymással versenyezhetnek a résztvevők. A játékmechanikai elemek közül a szociális ranglista az, amely a legnagyobb mértékben ösztönzi a résztvevőket a versenyzésre, teljesítményük fokozására.

Altruizmus (altruism). Az altruizmus fontos motivációs tényező egy olyan közösségben, ahol fontos a csapatmunka és a közös cél érdekében a tagoknak össze kell tartaniuk. Például csak akkor teljesíti a csapat a kihivást, ha mindenki egyénileg is teljesiti a feladatot.

A játékdinamika és a játékmechanika elemei egymással szorosan összefüggnek. Egymás közti viszonyukat a 3. ábra mutatja be. A sötétebb zöld négyzetek azokat az emberi vágyakat jelölik, amelyeket az adott játékmechanikai elemek elsődlegesen kielégítenek. Az ábrából láthatjuk, hogy a pontok a jutalmazás eszközei, a szintek az aktuális státusz jelölik, a kihívások a teljesitmény utáni vágyunkat elégítik ki, a virtuális javak az önkifejezésünkben segítenek, a ranglisták a versengési ösztönünket növelik, végül az ajándékok az altruista mivoltunkat támogatják (Fromann 2017). 


\begin{tabular}{|c|c|c|c|c|c|c|}
\hline & \multicolumn{6}{|c|}{ Játékdinamika - Emberi vágyak } \\
\hline Játékmechanika & 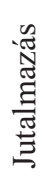 & 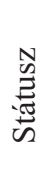 & 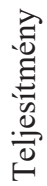 & 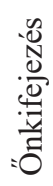 & 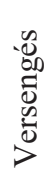 & 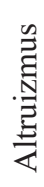 \\
\hline Pontok & & & & & & \\
\hline Szintek & & & & & & \\
\hline Kihívások & & & & & & \\
\hline Virtuális javak & & & & & & \\
\hline Ranglisták & & & & & & \\
\hline $\begin{array}{l}\text { Ajándékok és } \\
\text { jótékonyság }\end{array}$ & & & & & & \\
\hline
\end{tabular}

3.ábra: A játék dinamikája és mechanikája közötti kapcsolatok Forrás: Bunchball Inc. (2010)

Az esztétika az MDA modell harmadik és egyben utolsó eleme, mely leírja azt, hogy a játékosban milyen érzelmi reakciót vált ki a játék folyamata. Ezek az érzések származhatnak:

- valami új kipróbálásából,

- a kihívás teljesítéséböl,

- felfedezésböl és kalandból,

- a közösséghez való tartozásból,

- az önkifejezés lehetőségéből,

- a fantázia világába való elmerülésböl,

- a játékhoz való odaadásból,

- az érdekes és magával ragadó narratívából (Kusuma et al. 2018).

Most, hogy részletesebben ismertettük a gamification hatásmechanizmusait, némi rálátást kaptunk arról, hogy miért olyan népszerűek a videójátékok. Viszont a sikeres gamifikációhoz nem elég csupán az említett mechanizmusokat és dinamizmusokat használni. Ahhoz, hogy megértsük, miért is képes a fiatal generáció elme- 
rülni a játékokban, és mi a titka annak, hogy hosszú órákon keresztül folyamatosan kitart a motivációjuk, jobban meg kell vizsgálnunk a videójátékok „,varázsát”.

\section{A titkos formula}

A videójátékok készítői mesterei annak, miképp vonzzák be, korcsoportoktól függetlenül, az embereket a virtuális világukba. Milyen „csodarecept” szerint dolgoznak? A gamifikáció immerziv (elmerülési) hatásait vizsgálva Fromann (2012) a következőket állapította meg:

Optimális terhelés - a kihívások mindig alkalmazkodnak a játékosok képességeihez. Ha túl könnyen teljesithető a feladat, a kihívás elmarad és unalmassá válik. Nem motiválja kellöképp a résztvevőt. Ha viszont túl nehéz, akkor a motiváció helyett szorongás léphet fel.

Ideális beszintezés - a célok megfelelően vannak kialakitva. Ez egyrészt abban nyilvánul meg, hogy mindig van egy Nagy Cél, amelyet a játékos mindvégig szem előtt tart, másrészt van egy Nagy Történet, amely által a résztvevő érzi, hogy részese egy nagyobb dolognak. A Nagy Cél mellett a játékfejlesztők vigyáznak arra is, hogy a nagyon távoli, nehezen elérhető cél miatt a játékosok ne adják fel, így könnyebben elérhető kis célokra osztják fel a játékot. A kis célokra építik a visszacsatolást, szintlépést. Ez teszi lehetővé, hogy a játékos a feladat teljesítése után többször élje át a pozitiv, motiváló élményt.

Az ideális jutalomrendszer - az embereket nagymértékben motiválja az azonnali, pozitív visszacsatolás, amit többnyire a való életben nem kapnak meg, nem úgy, mint a videójátékok világában. A virtuális világban minden apró feladat teljesítéséért a játékos azonnali pozitiv visszacsatolást kap, mely mindig arányos a teljesítménnyel.

Most, hogy jobban megismertük a gamification logikai felépítését, valamit az egyes alkotóelemei közötti összefüggéséket, emellett az immerziv hatásának okait is, láthatjuk miért is sikeresek azok a játékok, melyeket ez alapján fejlesztettek ki.

\section{A játékosítás egyes elemei a felsőoktatásban}

Úgy vélem, a gamifikáció néhány eleme már jelen van a felsőoktatásban. A hallgatóka teljesítményükért pontokat kapnak, a pontok alapján pedig értékelést. Ha sikeresen teljesítik a tantárgyat, szintet lépnek, magasabb évfolyamba kerülnek. A pontok gyüjtése azért is motiváló, mert ha a hallgató rosszabbul teljesít és kevesebb pontot is kap egy-egy feladatra, egy kicsit akkor is közelebb kerül a célhoz. Az immerziv pszichológiai motiváció eleme is megtalálható. Az egyetemi tanulmányaik során a hallgatók lelki szemei előtt ott lebeg a Nagy Cél - sikeresen elvégezni az alap-, mester- vagy a doktoranduszi képzést. Hogy elérjék a Nagy Célt, számos kisebb célt kell teljesíteniük, és mindig egy kicsit közelebb kerülnek a végső célhoz. Ha 
az alapképzés a Nagy Cél, sikeresen kell teljesíteniük a megadott tantárgyakat, így magasabb évfolyamba kerülnek. A harmadik év végén ott az utolsó nagy akadály az államvizsga. Ha viszont a mesterképzés a Nagy Cél, akkor a sikeresen elvégzett alapképzés csak egy részcél lesz a Nagy Célhoz vezető úton.

Minél több játékelem és játékmechanika lesz beépítve az oktatásba, annál inkább be lehet majd vonni a hallgatókat az órai munkába, így növelve az aktivitásukat és motivációjukat.

\section{Konklúzió}

Az egyetemi padokat betöltő fiatalok - a multimédia hatása által - megnövekedett ingerküszöbbel rendelkeznek. Ezért nehezebb felkelteni az érdeklődésüket, nehezebb motiválni őket (Mezeiová 2018). Az internet hatására az agy képlékenysége miatt egy kicsit másképp „működik” az agyuk, mint az előző nemzedéknek. A hagyományos oktatás számukra ingerszegény, így nem kelti fel a figyelmüket. $\mathrm{Az}$ oktatóknak és a pedagógusoknak szükséges reagálniuk erre a helyzetre, és olyan módszereket kell alkalmazniuk, melyek a belső motivációra hatnak. Az egyik ilyen módszer az oktatási folyamatban különbözö játékelemeket és játékmechanikákat alkalmazó gamification. Kutatások alátámasztják, hogy a játék során megszerzett tudás sokkal mélyebben rögződik be az ember emlékezetébe. Ennek egyik oka, hogy a játék a belső motivációra hat. Hogy megértsük, miért képesek az amúgy „figyelmetlen és szétszórt fiatalok" órákon át maximálisan koncentrálva a kedvenc videójátékukat játszani, tudnunk kell, milyen elemeket tartalmaznak. Az MDA modell által a tanulmány bemutatja a játék egyes elemeit és a közöttük lévő kapcsolatokat.

Ha a mai fiatalok „csak a telefonjukat nyomkodják” és „más se jár a fejükben, csak a videójáték", akkor meg kell vizsgálni pedagógiai és pszichológiai szempontból, hogy miért van ez így. Az egyik válasz az lehet, hogy a videójátékok által alkalmazott MDA modell hatásos. Logikai struktúráját követve adaptálhatjuk a gamification módszereit az oktatásban is. A gamifikáció lehet az egyik legígéretesebb módszer arra, hogy hogyan motiváljunk és hogyan tegyük élvezetesebbé a tudásátadás folyamatát.

\section{Irodalom}

Bunchball, Inc. (2010): Gamification 101: An introduction to the use of game dynamics to influence behavior. White paper, 9.

Carr, Nicolas, G. (2010): The shallows: What the Internet is doing to our brains. New York: W. W. Norton.

Carr, Nicolas (2017): How smartphones hijack our minds. The Wall Street Journal, C1-C2. Christakis, Dimitrij A. (2011): The effects of fast-paced cartoons. Pediatrics, 128/4, 772774. 
Crone Eveline A. - Konijn, Elly A. (2018): Media use and brain development during adolescence. Nature communications, 9/1, 1-10.

Csikszentmihalyi, Mihály (1997): Finding flow: The psychology of engagement with everyday life. Basic Books.

Deterding, S. (2011): Situated motivational affordances of game elements: A conceptual model. In: Gamification: Using game design elements in non-gaming contexts, a workshop at CHI 2425-2428.

Fromann Richárd (2017): Játékoslét: A gamifikáció világa. Typotex Budapest.

Hanson, Rick (2017): Positive neuroplasticity: The neuroscience of mindfulness. In: Advances in Contemplative Psychotherapy. Routledge, 48-60.

Hunicke, Robin - LeBlanc, Mark - Zubek, R. (2004, July): MDA: A formal approach to game design and game research. In Proceedings of the AAAl Workshop on Challenges in Game Al 4/1 1722.

Huotari, Kai - Hamari, Juho (2017): A definition for gamification: anchoring gamification in the service marketing literature. Electronic Markets, 27/1, 21-31.

Junco, Reynol - Cotten, Shelia R. (2012): No A 4 U: The relationship between multitasking and academic performance. Computers \& Education, 59/2, 505-514.

Kapp, Karl M. (2012): The gamification of learning and instruction: game-based methods and strategies for training and education. John Wiley \& Sons.

Karp, Scott: „The Evolution from Linear thought to Networked Thought”. Publishing 2.0 blog, 2008. február 9. Online: https://publishing2.com/2008/02/09/the-evolution-fromlinear-thought-to-networked-thought/ (Letöltés: 2020. 1. 10.)

Kirschner, Paul. A. - Karpinski, Aryn C. (2010): Facebook ${ }^{\circledR}$ and academic performance. Computers in human behavior, 26/6, 1237-1245.

Kusuma, G. P. - Wigati, E. K. - Utomo, Y. - Suryapranata, L. K. P. (2018): Analysis of Gamification Models in Education Using MDA Framework. Procedia Computer Science, 135, 385-392.

Mezeiová, Adriana (2018): A játékositás oktatásbeli felhasználásának elméleti vizsgálata In: Zborník 10. medzinárodnej vedeckej konferencie Univerzity J. Selyeho - 2018. Komárno: Univerzita J. Selyeho, 194-204.

Mezeiová, Adriana - Bencsik Andrea (2019): A játékositott tudásátadás igénye a felsőoktatásban. International Conference of J. Selye University, 11. Komárno: Univerzita J. Selyeho, 233-243.

Miall, David S. - Dobson, Teresa (2001): Reading hypertext and the experience of literature. Journal of digital information, 2/1.

Monk, Christopher A. - Trafton, Gregory J. - Boehm-Davis, Deborah A. (2008): The effect of interruption duration and demand on resuming suspended goals. Journal of Experimental Psychology: Applied, 14/4, 299-318.

Nicholas, D. - Rowlands, I. - Jamali, H. R. (2010): E-textbook use, information seeking behaviour and its impact: Case study business and management. Journal of information Science, 36/2, 263-280.

Nielsen, Jacob (2007): F-shaped pattern for reading web content. Online: <www. nngroup. com/articles/f-shaped-pattern-reading-web-content> (Letöltés: 2020. 1. 17.)

Pric, Rebecca. B. - Duman, Roland (2019): Neuroplasticity in cognitive and psychological mechanisms of depression: an integrative model. Molecular Psychiatry, 1-14. 
Raftopoulos, Marigo (2016): How organisations play: creating stakeholder value with enterprise gamification.

Shrestha, S. - Lenz, K. (2007): Eye gaze patterns while searching vs. browsing a Website. Usability News, 9/1, 1-9.

Steigerwald, Joan (2014): Treviranus' Biology: Generation, Degeneration, and the Boundaries of Life. In: Reproduction, Race, and Gender in Philosophy and the Early Life Sciences, 2014, 105-127.

Tari Annamária (2015): Generációk online. Budapest: Tericum Kiadó.

Uncapher, Melinda R. - Wagner, Anthony D. (2018): Minds and brains of media multitaskers: Current findings and future directions. Proceedings of the National Academy of Sciences, 115/40, 9889-9896.

University College london. „Information Behaviour of the researcher of the Future”. Online: <https://www.researchgate.net/publication/200760622_Information_behaviour_of_the_ researcher_of_the_future> (Letöltés: 2020. 1. 21.)

Valkenburg, Patti M. - Peter, Jochen - Walther, Joseph B. (2016): Media effects: Theory and research. Annual review of psychology, 67, 315-338.

Yu-kai Chou: Gamification, Manipulation, and Ethics. Online: <https://yukaichou.com/gamification-study/gamification-manipulation-ethics/> (Letöltés: 2020. 2. 1.) 